\title{
PENERAPAN METODE PEMBELAJARAN BRAINSTORMING DALAM MENINGKATKAN HASIL BELAJAR MATA PELAJARAN BAHASA INDONESIA PADA SISWA KELAS V SDN 164319 TEBING TINGGI
}

\author{
Rismawaty Tampubolon \\ Surel: rismawaty.tmbln@gmail.com
}

\begin{abstract}
The aim of this research is to improve learning result on Indonesian Language subject through brainstorming method. This classroom action research conducted by 2 cycles of the four phases: planning, implementation, observation, reflection. The subjects were students from grade V, SD Negeri 164319 Tebing Tinggi which amounted to 33 students. This study used a qualitative descriptive analysis technique. The results showed that the method of the brainstorming in Indonesian Language subject can improve student learning result characterized by increased mastery learning students, namely pre-cycle (69,7\%), the first cycle (81,8\%), cycle II (90,9\%) and complete learn the clasical equal to 90,9\%.
\end{abstract}

Keywords: Brainstorming, Indonesian Language

\begin{abstract}
ABSTRAK
Penelitian ini bertujuan untuk meningkatkan hasil belajar siswa mata pelajaran Bahasa Indonesia melalui metode brainstorming. Penelitian tindakan kelas ini dilaksanakan sebanyak 2 siklus dengan empat tahapan yaitu: perencanaan, pelaksanaan, observasi, refleksi. Subjek penelitian ini adalah siswa kelas V SD Negeri 164319 Tebing Tinggi sebanyak 33 siswa. Penelitian ini menggunakan teknik analisis dekriptif kualitatif. Hasil penelitian menunjukkan bahwa penggunaan metode brainstorming mata pelajaran Bahasa Indonesia dapat meningkatkan hasil belajar siswa yang ditandai dengan peningkatan ketuntasan belajar siswa, yaitu pra siklus $(69,7 \%)$, siklus I $(81,8 \%)$, siklus II $(90,9 \%)$ dan dinyatakan berhasil secara klasikal 90,9\%.
\end{abstract}

Kata Kunci: Brainstorming, Bahasa Indonesia

\section{PENDAHULUAN}

Saat ini proses pendidikan beralih dari yang berpusat pada pendidik menjadi berpusat pada peserta didik. Peserta didik dituntut untuk lebih aktif dalam proses pembelajaran sementara pendidik mengawasi sekaligus memfasilitasi peserta didik untuk mencapai tujuan belajar. Salah satu masalah yang dihadapi pendidikan saat ini adalah lemahnya kualitas proses pembelajaran. Proses pembelajaran masih bersifat hapalan yang berakibat pada lebih mementingkan isi daripada proses (Holmqvist, 2014). Selain itu siswa pun kurang diarahkan pada proses pembelajaran yang menghubungkan materi dengan kehidupan sehari-hari siswa.

Bahasa Indonesia adalah alat komunikasi yang dipergunakan oleh masyarakat Indonesia untuk keperluan sehari-hari, misalnya belajar, bekerja sama dan berinteraksi (Cahyani, 2009: 36). Kegiatan pembelajaran Bahasa Indonesia akan berhasil apabila guru menyesuaikan pembelajaran dengan kemampuan siswa. Penyesuaian tersebut harus dirancang secara terpadu dengan tujuan pembelajaran 
Bahasa Indonesia. Strategi pembelajaran Bahasa Indonesia mengacu pada perilaku dan proses berpikir yang digunakan oleh siswa yang mempengaruhi apa yang dipelajari, termasuk mengingat dan metakognitif.

Belajar adalah modifikasi atau memperteguh kelakuan melalui pengalaman (learning is defined as the modification or strengthening of behavior through experiencing) (Hamalik,2011:27). Sedangkan hasil belajar merupakan bagian terpenting dalam pembelajaran.Sudjana (2009: 3) mendefinisikan hasil belajar siswa pada hakikatnya adalah perubahan tingkah laku sebagai hasil belajar dalam pengertian yang lebih luas mencakup bidang kognitif, afektif, dan psikomotorik.

$\begin{array}{rrr} & \text { Berdasarkan hasil observasi } \\ \text { siswa } & \text { setelah } & \text { melakukan }\end{array}$
pembelajaran di prasiklus dengan guru kelas V di SD Negeri 164319 Tebing Tinggi, diperoleh hasil ketuntasan belajar hanya sebanyak 23 siswa dari 33 siswa $(69,7 \%)$. Hasil observasi menunjukkan siswa masih pasif hanya beberapa orang siswa saja yang aktif bertanya dan mengemukakan pendapat atau ide, sedangkan yang lain nya hanya diam dan sebagian siswa merasa takut untuk bertanya dan ada juga yang tidak bisa mengungkapkan pertanyaan secara lisan walaupun ada hal yang tidak dipahaminya.

Selain pembelajaran aktif, Guru juga seharusnya lebih beragam menggunakan metode pembelajaran agar siswa di dalam kelas tidak bosan.
Dalam kaitannya dengan metode guru harus memilih beberapa metide yang menuntut siswanya untuk aktif.salah satu metode pembelajaran yang dianggap tepat pada mata pelajaran Bahasa Indonesia adalah dengan metode brainstorming. Metode brainstorming ialah suatu teknik atau cara mengajar yang dilaksanakan oleh guru di dalam kelas dengan cara melontarkan suatu masalah ke kelas, kemudian siswa menjawab atau menyatakan pendapat, atau komentar sehingga mungkin masalah tersebut berkembang menjadi masalah baru, atau dapat diartikan pula sebagai satu cara untuk mendapatkan banyak ide dari sekelompok manusia dalam waktu yang sangat singkat (Roestiyah, 2008:73).

Brainstroming adalah piranti perencanaan yang dapat menampung kreativitas kelompok dan sering digunakan sebagai alat pembentukan untuk mendapatkan ide-ide yang banyak, dan metode brainstorming merupakan salah satu cara mendapatkan sejumlah ide yang mudah dan menyenangkan para pesertanya. Pada dasarnya brainstorming adalah salah satu bentuk diskusi kelompok yang bertujuan untuk mencari solusi yang lebih aktif dengan gagasan-gagasan yang muncul dari para siswa.Implementasi metode brainstorming pada penelitian ini menekankan peningkatan kreativitas. Oleh karena itu, pembelajaran menekankan ranah psikomotor, sebab ranah psikomotor sudah mencakup pula ranah afektif dan kognitif. 
Menurut Widowati (2009: 4), tahapan metode brainstorming mencakup: preparation (persiapan), fact-finding (pencarian fakta), warm up (pemanasan), idea finding (pencarian ide), solution finding (pencarian solusi), dan implementation (pelaksanaan). Dalam metode ini siswa dituntut lebih aktif dalam mengemukakan pendapatnya lebih luas mendapat pengetahuan dan mengupayakan agar hasil belajar dapat bertahan lama dikuasai siswa. Ide yang muncul lebih banyak dan beragam karena siswa dengan bebas menyalurkan ide tersebut tanpa adanya kritik. Senada dengan pendapat Alrubaie dan Esther (2014: 44) bahwa kelebihan metode brainstorming diantaranya yaitu: membangun pengetahuan, meningkatkan kemampuan mental dan membantu siswa dalam belajar dengan tanpa ada kritik, aturan atau evaluasi dalam pembatasan pembatasan menghasilkan ide.

Tujuan dari penelitian ini adalah untuk meningkatkan Meningkatkan kemampuan berpendapat siswa yang nantinya berdampak pada hasil belajar siswa kelas V SD Negeri 164319 Tebing Tinggi tahun pembelajaran 2018/2019 melalui metode brainstorming pada mata pelajaran Bahasa Indonesia.

\section{METODE PENELITIAN}

Penelitian ini dilaksanakan pada bulan September sampai dengan bulan Maret sampai April 2019 pada semester genap tahun ajaran
2018/2019. Penelitian ini dilaksanakan dalam 2 siklus, yaitu siklus pertama selama 2 kali pertemuan dan siklus kedua selama 2 kali pertemuan. Peneliti mengambil lokasi penelitian tindakan kelas di SD Negeri 164319 Tebing Tinggi.

Subyek penelitian adalah siswa kelas V SD Negeri 164319 Tebing Tinggi dengan jumlah siswa sebanyak 33 orang dengan 15 orang laki-laki dan 17 orang perempuan. Sumber data yang digunakan adalah siswa dan teman sejawat. Pada Penelitian tindakan kelas data yang dikumpulkan dapat berbentuk kuantitatif maupun kualitatif.

Bentuk penelitian ini adalah Penelitian Tindakan Kelas (classroom action research). Arikunto (2008: 3) Penelitian tindakan kelas merupakan suatu pencermatan terhadap kegiatan belajar berupa sebuah tindakan, yang sengaja dimunculkan dan terjadi disebuah kelas secara bersama, tindakan tersebut. Model penelitian tindakan kelas yang digunakan peneliti adalah sistem spiral refleksi diri yang dikembangkan oleh Kemmis dan Taggart yang dimulai dengan perencanaan, tindakan, pengamatan, dan refleksi.

\section{Perencanaan}

Pada tahapan ini dilakukan berbagai persiapan dan perencanaan tindakan yang meliputi: menyusun skenario pembelajaran berupa Rencana Pelaksaan Pembelajaran, mempersiapkan media pembelajaran dan alat observasi, dan membuat 
instrumen untuk evaluasi yang berupa soal tes tertulis. Selain mempersiapkan hal-hal tersebut, untuk dapat melaksanakan penelitian ini dengan tujuan yang jelas peneliti juga perlu menetapkan indikator ketercapaian dalam penerapan metode brainstorming.

\section{Pelaksanaan}

\section{Siklus I}

Guru yang melakukan pembelajaran di dalam kelas dengan menggunakan panduan perencanaan yang telah dibuat. Siklus I dilakukan pada tanggal 12 dan 14 Maret 2020. Guru menyajikan dan menjelaskan materi ajar dan menerapkan metode brainstorming. Guru memberikan sebuah permasalahan yang akan dipecahkan oleh siswa dan menetapkan batasan waktu yang diperlukan untuk memikirkan jawaban secara pribadi oleh siswa. Setelah itu guru memberikan kesempatan kepada siswa untuk menyampaikan pendapatnya

Pada saat kegiatan pembelajaran berlangsung guru sebagai peneliti dibantu oleh para observer lainnya untuk melakukan pengamatan, mendokumentasi kegiatan, selain itu peneliti bertindak sebagai fasilitator, motivator dan sekaligus sebagai pengamat. Guru melakukan postes untuk mengetahui hasil belajar siswa yang dilakukan pada pertemuan berikutnya.

\section{Siklus II}

Siklus II dilakukan pada tanggal 19 dan 21 Maret 2019. Guru melakukan pembelajaran di dalam kelas dengan menggunakan panduan perencanaan yang telah dibuat. Guru melakukan pembelajaran di dalam kelas dengan menggunakan panduan perencanaan yang telah dibuat. Pada siklus II pelaksanaan tindakan dilkakukan hampir sama dengan siklus I namun dilaksanakan ke arah yang lebih baik setelah dilakukan refleksi pada siklus I. Jika pada siklus ke II tindakan yang diberikan sudah sesuai dengan yang diharapkan atau tindakan tersebut sudah bisa dikatakan berhasil dalam meningkatkan hasil belajar siswa dengan menggunakan model pembelajaran Brainstorming, maka peneliti tidak perlu untuk melanjutkan pada siklus selanjutnya.

\section{Observasi/Pengamatan}

Observasi digunakan untuk pengumpulan data aktivitas belajar bahasa Indonesia siswa dalam pembelajaran. Pengumpulan data melalui observasi dilakukan secara partisipatif, yang berarti pengamat ikut serta dalam kegiatan belajar mengajar yang dilakukan oleh subjek yang diamati (Sanjaya, 2010: 92). Pengamatan dilakukan peneliti sendiri dan dibantu oleh pengamat dan mencatat proses penerapan teknik pengajaran kolaborasi.

\section{Refleksi}

Peneliti mengkaji, melihat dan mempertimbangkan hasil atau dampak dari tindakan yang dilakukan berdasarkan lembar pengamatan yang diisi oleh pengamat. Kegiatan pada 
tahap refleksi meliputi kegiatan menganalisis, memahami dan membuat kesimpulan berdasarkan hasil observasi setiap siklus. menemukan kelebihan dan kelemahan tindakan perbaikan pembelajaran. Hasil analisis data yang dilaksanakan pada tahap ini akan dipergunakan untuk menemukan kelebihan dan kelemahan diri dalam merancang dan melakukan tindakan sebagai acuan.

Instrumen yang digunakan dalam penelitian ini adalah pedoman observasi, test hasil belajar, dan wawancara. Data aktivitas belajar dan kendala yang dihadapi selama proses pembelajaran dikumpulkan melalui observasi (lembar observasi terlampir). Hal-hal yang akan diobservasi adalah kegiatan lisan, kegiatan metrik, kegiatan emosional. Data hasil observasi, dan data hasil wawancara yang jenis datanya berupa pernyataan-pernyataan, dianalisis dengan menggunakan teknik analisis statistik deskriptif.

Metode pengumpulan data penelitian ini adalah tertulis dan observasi. Penelitian ini dikatakan berhasil apabila siswa telah memperoleh nilai ketuntasan secara klasikal minimal 85\% dari jumlah siswa dengan rumus sebagai berikut:

Persentase Ketuntasan klasikal $=$ Jumlah siswa yang tuntas $\quad \times 100 \%$ Jumlah siswa yang mengikuti tes

\section{HASIL PENELITIAN DAN PEMBAHASAN}

Dalam pelaksanaan penelitian ini data yang diperoleh dari presentase ketuntasan belajar untuk mengamati aktivitas siswa selama proses pembelajaran berlangsung. Dari hasil analisis tes awal tersebut peneliti memeriksa bahwa dari 33 orang siswa yang mengikuti tes tersebut, hanya terdapat 23 orang siswa yang dapat menyelesaikan soal dengan benar. Hal ini menunjukkan bahwa pemahaman siswa mengenai materi yang diberikan masih rendah sehingga tidak mencapai ketuntasan klasikal yang telah ditetapkan. Oleh karena itu, sebelum masuk pada tahap pelaksanaan tindakan, peneliti bersama para siswa kelas V SD 164319 Tebing Tinggi membahas soal tes awal tersebut.

Peneliti melaksanakan tes awal yang bertujuan untuk mengetahui kemampuan awal siswa mata pelajaran Bahasa Indonesia sesuai dengan RPP dan untuk dijadikan alat dalam pembentukan kelompok yang bersifat heterogen. Pemberian materi disini tidak serta merta hanya peneliti yang disini berperan langsung sebagai pengajarnya yang aktif, melainkan juga peserta diminta untuk ikut andil juga. Hasil penelitian tindakan kelas menunjukkan bahwa pengamatan yang dilakukan oleh mitra kolaborasi dan peneliti pada aktivitas guru dan siswa melalui penerapan metode brainstorming pada mata pelajaran Bahasa Indonesia di kelas V SD Negeri 164319 Tebing Tinggi dapat dilihat pada Tabel 1 yaitu sebagai berikut : 
Tabel 1. Peningkatan Hasil Belajar Siswa Pra Siklus, Siklus I dan II

\begin{tabular}{c|c|c|c}
\hline \multicolumn{2}{c|}{ Peningkatan Hasil Belajar } & \multirow{2}{*}{ Keterangan } \\
\hline $\begin{array}{c}\text { Pra } \\
\text { Siklus }\end{array}$ & Siklus I & Siklus II & \\
\hline 69,7 & 27 & 30 & $\begin{array}{c}\text { Jumlah } \\
\text { Siswa } \\
\text { Tuntas } \\
\text { Belajar }\end{array}$ \\
\hline 70,7 & 78,2 & 87,5 & $\begin{array}{c}\text { Persentase } \\
\text { Ketuntasan } \\
\text { Belajar }(\%)\end{array}$ \\
\hline $\begin{array}{c}\text { Tidak } \\
\text { Tuntas }\end{array}$ & $\begin{array}{c}\text { Tidak } \\
\text { Tuntas }\end{array}$ & Tuntas $(\%)$ & $\begin{array}{c}\text { Ketuntasan } \\
\text { Secara } \\
\text { Klasikal }\end{array}$ \\
\hline
\end{tabular}

Berdasarkan pengamatan peneliti dari tindakan pra siklus, siklus I dan II terjadi peningkatan hasil belajar dan aktivitas siswa melalui persen ketuntasan belajar secara klasikal. Pada siklus I sebanyak 27 siswa tuntas secara klasikal atau diperoleh $81,8 \%$ ketuntasan belajar siswa. Hal ini berarti terjadi peningkatan ketuntasan belajar sebesar 12,1\% dari prasiklus. Sedangkan untuk aktivitas belajar siwa diperoleh $78,2 \%$ atau terjadi peningkatan sebesar 7,5\% .

Berdasarkan hasil belajar siswa pada siklus I, dalam pelaksanaannya siswa sudah mampu mengungkapkan pikiran, perasaan, dan fakta tertulis dalam bentuk ringkasan atau pokok-pokok dari isi cerita. Meskipun terjadi peingkatan hasil belajar siswa dari pra siklus ke siklus I namun hasilnya belum sesuai dengan indikator keberhasilan. Pada saat pelaksanaan kegiatan belajar awalnya siswa kurang memberikan respon dan asik sendiri dengan aktivitas mereka dikarenakan kurang aktif dan kurang paham dalam melaksanakan persentase ini, tetapi setelah

pertemuan kedua respon yang ditunjukkan semakin positif dan mereka merasa senang dan semangat dalam setiap kali proses pembelajaran, terlebih lagi setelah presentase setiap kelompok yang mendapat nilai paling tinggi mendapatkan penghargaan berupa hadiah pulpen. Dengan demikian, dapat disimpulkan bahwa keaktifan siswa telah memenuhi target indikator kinerja dalam pelaksanaan tindakan kelas ini dengan menggunakan metode brainstorming dalam pembelajaran Bahasa Indonesia kelas V SDN 164319 tahun ajaran 2018/2019.

Brainstorming mengajarkan anak untuk belajar menemukan sendiri bagaimana suatu konsep pengetahuan dalam sebuah pembelajaran. Penemuan gagasan dan konsep pembelajaran peserta didik dibangun berdasarkan pengalaman dan hasil diskusi kelompok yang telah mereka lakukan. Setiap gagasan yang dikemukaan oleh peserta didik ditulis, kemudian setelah semua gagasan telah terkumpul, masing-masing kelompok melakukan seleksi, dengan persetujuan dan konfirmasi dari semua anggota kelompok.

Metode pembelajaran brainstorming pada siklus II diperoleh ketuntasan belajar mencapai $90,9 \%$ atau ada 30 siswa dari 33 siswa sudah tuntas belajar. Dengan mencermati data hasil tes akhir siklus II, dapat dinyatakan 
bahwa terjadi peningkatan yang signifikan pada hasil belajar. Hasil tersebut menunjukkan bahwa pada siklus kedua secara klasikal sudah tuntas belajar dan sudah memenuhi kriteria dari persentase ketuntasan yang dikehendaki yaitu sebesar $85 \%$. Sedangkan untuk persentase aktvitas siswa mencapai 87,5\%. Hasil belajar pada siklus II dikatakan tuntas karena sudah mencapai bahkan melebihi $85 \%$.

Penerapan implementasi metode Brainstorming pada siklus II dapat terlaksana dengan maksimal. Setiap anggota mempunyai kontribusi masing-masing dalam penyelesaian tugasnya. Peningkatan hasil belajar pada siklus II ini disebabkan siswa sudah paham dengan apa yang harus dikerjakan saat pembelajaran berlangsung, serta antara guru dan siswa mampu bekerjasama dengan baik dan tidak ada dominasi lagi dalam setiap kelompok. Dengan meningkatnya hasil belajar siswa pada siklus II dapat dikatakan siswa telah paham dengan materi yang diajarkan dengan penerapan implementasi metode brainstorming berdasakan tujuan pembelajaran yang dirumuskan.

Dengan penerapan metode brainstorming, siswa bertugas menanggapi masalah dengan mengemukakan pendapat, komentar, bertanya, atau mengemukakan masalah baru. Mereka belajar dan berlatih merumuskan pendapat dengan bahasa dan kalimat yang baik. Siswa yang kurang aktif perlu dipancing dengan pertanyaan agar ia turut berpartisipasi aktif dan berani mengemukakan pendapatnya. Hal ini juga sependapat dengan Roestiyah (2008:73) yang menyatakan bahwa metode brainstorming ialah suatu teknik atau cara mengajar yang dilaksanakan oleh guru di dalam kelas dengan cara melontarkan suatu masalah ke kelas, kemudian siswa menjawab atau menyatakan pendapat, atau komentar sehingga mungkin masalah tersebut berkembang menjadi masalah baru, atau dapat diartikan pula sebagai satu cara untuk mendapatkan banyak ide dari sekelompok manusia dalam waktu yang sangat singkat.

Melihat kenyataan diatas, maka penerapan metode brainstroming dalam pembelajaran Bahasa Indonesia. Walaupun masih ada anak yang mengalami berbagai kesalahan, namun secara keseluruhan dapat dikatakan mengalami peningkatan secara bertahap. Selain itu, penerapan metode brainstorming di kelas berdasarkan hasil pengamatan di kelas, peserta didik terlihat aktif dalam proses pembelajaran. Metode pembelajaran brainstorming terbukti dapat memengaruhi hasil belajar peserta peserta didik, dari ranah kognitif, dari segi pengetahuan dan pemahaman, peserta didik akan berpikir keras mengenai satu masalah yang diajukan oleh guru yang akan menguras pikiran, dari proses berpikir tersebut peserta didik akan menjadi lebih paham atas apa yang yang diajukan oleh guru khususnya dalam pembelajaran Bahasa Indonesia. 


\section{Pembahasan}

Berdasarkan hasil yang didapat dari setiap siklus proses pembelajaran yang optimal. Hal ini ditunjukkan dengan meningkatnya penguasaan materi dan hasil belajar siswa. Oleh karena itu dapat disimpulkan bahwa proses pembelajaran dengan penerapan metode brainstorming sesuai dengan mata pelajaran Bahasa Indonesia. maka Penelitian Tindakan Kelas (PTK) ini bisa dikatakan berhasil karena hasil peningkatan proses pembelajarannya optimal. Gambaran peningkatan ketuntasan belajar pada siklus I dan II dengan menggunakan metode brainstoming terlihat pada diagram berikut:

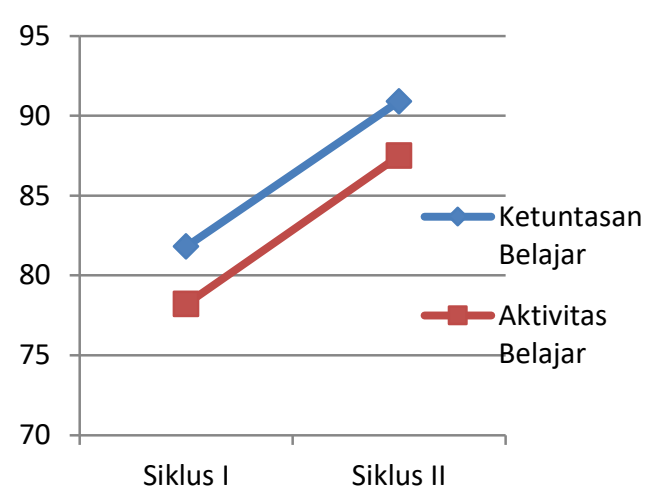

Gambar 1. Diagram Garis Peningkatan Ketuntasan Belajar

\section{SIMPULAN}

Dari hasil temuan penelitian tentang hasil belajar siswa melalui penerapan metode brainstorming di kelas V SD Negeri 164319 Tebing Tinggi tahun pelajaran 2018/2019 disimpulkan mampu meningkatkan hasil belajar siswa pada mata pelajaran Bahasa Indonesia. Hal tersebut dapat dilihat dari peningkatan persentase ketuntasan belajar siswa pada siklus I (81,8 \%), siklus II (90,9\%). Sedangkan untuk aktivitas belajar siswa pada siklus I yaitu $78,2 \%$ dan meningkat menjadi $87,5 \%$ pada siklus II.

\section{DAFTAR RUJUKAN}

Alrubaie dan Esther. 2014. Revisiting The Cognitive Processes of The Brainstorming Technique. Teoritical Considerations from a Synthesis of Piaget, Vygotsky and SIAM of Learning Science. 18 Januari 2019. Dikutip dari: https://www.google._com/_rev isiting_thecognitiveprocessesof thebrainstormingtechnique-pdf

Cahyani, I. 2006. Pembelajaran Bahasa Indonesia. Jakarta: Cet. pertama.

Grietje, K.H dan E.P Uneputty. 2013. Pengaruh Metode

Brainstroming Terhadap Hasil Belajar Bahasa Jerman Siswa Kelas XI SMA Negeri 3 Ambon. Ambon: Jurnal Penelitian Dosen Program Studi Pendidikan Bahasa Jerman FKIP Universitas Pattimura Ambon.

Hamalik, Oemar. 2011. Proses Belajar Mengajar. Jakarta: Bumi Aksara.

Holmqvist, M. 2014. Experiential Learning Processes of Exploitation and Exploration Within and Between Organizations: An Empirical Study of Product Development. Organization Science, 15(1), 70-81.

Luthfiyati N.A, Elah Nurlaela, Dian Usdiyana. 2013. Model Pembelajaran Osborn .Bandung: Jurnal Penelitian. 
Rismawaty Tampubolon : Penerapan Metode ...

Roestiyah N.K. 2018. Strategi Belajar Mengajar. Jakarta: Rineka Cipta.

Sanjaya, Wina. 2010. Penelitian Tindakan Kelas. Jakarta: Kencana Prenada Media Group. Sudjana, Nana. 2009. Dasar-Dasar Proses Belajar Mengajar. Bandung: Sinar Baru Algesindo.

Widowati, Asri. 2009. Brainstorming sebagai Alternatif Pengembangan Berfikir Kreatif dalam Pembelajaran Sains Biologi. Laporan Penelitian. Yogyakarta : UNY. 